\title{
Manifesting Sustainable Development Goals through the Development of Regional Island Cluster Characterized by Archipelago: International Law Perspectives
}

\author{
Dyah Ridhul Airin Daties $^{1} \quad$ S.M. Noor ${ }^{2} \quad$ M. Ashri ${ }^{2} \quad$ Juajir Sumardi $^{2}$ \\ 1.PhD Students at Postgraduate Programme, Faculty of Law, Hasanuddin University \\ 2.Professor on Legal Science, Faculty of Law, Hasanuddin University
}

\begin{abstract}
Article 1 of the 1933 Montevideo Convention stipulates that territory is one of the most important elements of a state. As a sovereign state, Indonesia has regions whose territory is characterized by archipelago. Maluku as one of the islands characterized by archipelago is the founder of the concept of island cluster development. The development of this island cluster, if utilized by the regional government to attract foreign cooperation, will be an opportunity to realize the goals of sustainable development (SDGs).
\end{abstract}

Keywords: SDGs, Regional Island Cluster, Archipelago, International Law

DOI: $10.7176 / \mathrm{JLPG} / 88-05$

Publication date: August $31^{\text {st }} 2019$

\section{Introduction}

Towards the end of the era Development Goals Millennium or the Millennium Development Goals (MDGs) by 2015, the United Nations (UN) organized the conference titled sustainable development in Rio de Janeiro, Brazil, in June 2012, or more often called with Conference on Rio+20. The meeting produced the future we want document ${ }^{1}$ that was a very important role in the emergence of Sustainable Development Goals. The most important point of the document is the need for a new sustainable development agenda to continue the MDGs with a broader, holistic and universal vision.

As a follow up to the Rio +20 meeting, the UN formed a special working group whose task was to prepare a proposal on the concept of sustainable development after the MDGs on 22 January $2013 .^{2}$ The team consisted of 30 members, including Indonesia as a representative of the Asia Pacific group. After passing negotiations between countries, the final document produced by the team was adopted by more than 150 world leaders on the occasion of the UN Sustainable Development Summit, on September 25-27 in New York, United States. In the meeting, all countries present declared jointly to adopt a new sustainable development agenda, namely Transforming our world: the 2030 Agenda for Sustainable Development ${ }^{3}$ or known as Sustainable Development Goals (SDGs).

SDGs birth is not free from criticism. It is because the target achievements are more complex and more many of the MDGs. The SDGs contain 17 goals and are divided into 169 targets to make human life better. So, do not be surprised if the SDGs are considered as a global vision that is too ambitious. However, other perspectives assume that it is precisely that this ambitious is needed to be able to "force" all parties to participate in solving the challenges of the world's big development, such as inequality and environmental damage. In addition, differences in the principle of drafting between SDGs and MDGs provide hope that the world will transform into a better place to live. In principle, the MDGs focus on development issues in developing and underdeveloped countries, where developed countries play a greater role as donors. On the other hand, the main principles of the SDGs are universally applicable, with development goals that apply to all underdeveloped, developing countries and move forward, with each of its citizens.

Unlike the MDGs, the methods and the ways of implementing the SDGs require citizen participation. One way to ensure the achievement of all SDGs goals and targets is to involve civil society groups. The government is responsible for forming a joint institution / secretariat for sustainable development in the country. In Indonesia, the implementation of the SDGs agenda builds on the government's experience implementing the MDGs agenda. Under the direction of President Joko Widodo, Indonesia is very serious in achieving the SDGs indicators . This started with the integration of 169 SDGs indicators into the National Medium Term Development Plan (RPJMN) 2020 - 2040. Even the Presidential Regulation (Perpres) No. 59 of 2017 came out on the Implementation of Sustainable Development Goals. This shows that the government's consistency in institutionalizing the SDGs agenda in the national development program. Perpres No. 59 of 2017 Concerning the Implementation of Sustainable Development Goals emphasizes the involvement of all stakeholders, through 4 platforms of

\footnotetext{
${ }^{1}$ See https://sustainabledevelopment.un.org/futurewewant.html, accessed 5 June 2019.

${ }^{2}$ See http://www.un.org/ga/search/view_doc.asp?symbol=A/67/L.48/Rev.1\&Lang=E, accessed 5 June 2019.

${ }^{3}$ Seehttps://sustainabledevelopment.un.org/content/documents/21252030\%20Agenda $\% 20$ for\%20Sustain able\%20Development $\% 20$ web.pdf, accessed 5 June 2019.
} 
participation namely: the government and parliament, philanthropic and business actors, mass organizations, as well as academics and experts in order to successfully implement the SDGs agenda. For Indonesia, SDGs is not only relevant to global commitments, but is also a guide to becoming a developed country. It also shows that the government takes full responsibility for implementing the SDGs agenda in Indonesia.

SDGs can also be used by the Indonesian government to improve the welfare of the community, especially people in provinces that are characterized by islands. Empirical phenomena that can be seen concretely related to the characteristics of the archipelago are:

a. limited basic service facilities and infrastructure;

b. limited regional financial capacity;

c. very minimal sea and air transportation facilities and infrastructure;

d. transportation costs in the context of very expensive government services;

e. limited public accessibility in general;

f. physical and social isolation still exists;

g. there is a very high fiscal dependence on the government;

h. the quality of various government services, both public and civil services;

i. $\quad$ there are still economic disparities between regions; and

j. $\quad$ poor quality of human resources. ${ }^{1}$

This fact holds the state responsibility because of the state aims to create public welfare. This means that the state is obliged to help and support the efforts of the community to build a life in which all members can live properly. ${ }^{2}$ To achieve this goal, the government needs the support of every stakeholder, especially from the structure of the government itself.

One of the provinces characterized by islands in Indonesia is the province of Maluku. Maluku governments since 1992 have downloaded the design of a development concept the island's cluster. Unfortunately, 25 years the island clusters development has been developed, apparently until now it cannot be realized properly. Even the concept of development that is adapted to the geographical and socio-cultural conditions of the Maluku people, it seems not well understood so that it has not been implemented optimally by policy makers in the Maluku government both at the provincial and district / city levels. In addition to historical factors and potential factors of natural resources in the sea and coast, the waters of the Moluccas also lie along the Indonesian Archipelagic Sea Lane (ALKI) III.

This paper will review to what extent International Law provides juridical opportunities for archipelagic regions, particularly the Maluku province to realize the MDGs through the construction of island clusters that have been developed by the Maluku government.

\section{Research methods}

This research was normative legal research. It applied 2 (two) data collection techniques, namely library research and interviews in order to obtain legal material. Primary legal material came from the rules of international law and national law related to the substance of writing. Secondary legal material was obtained from documents and literature that included relevant theories and doctrines. The tertiary legal material was obtained from explanations and information obtained from materials outside of primary legal materials and secondary legal materials, but supports the legal analysis in this paper. Those legal materials were then described descriptively, systematically and logically in order to draw specific conclusions.

\section{Discussion}

Article 1 of the 1933 Montevideo Convention Concerning the Rights and Obligations of a State. The article stipulates that "the state as a person of international law should have the following qualifications:

a. A permanent population;

b. A defined territory;

c. Government; and

d. Capacity to enter into relations with the other states".

The article states that as a person of international law, the state must meet the following requirements: permanent population, certain territories, governments, and the ability to establish external relations with other countries.

As a sovereign state, Indonesia fulfils the qualifications of Article 1 of the 1933 Montevideo Convention. Regarding the state's territory, Article 25 of the 1945 Constitution states that "the Unitary State of the Republic of Indonesia is an archipelagic country characterized by the archipelago with territories and boundaries and its

\footnotetext{
${ }^{1}$ Johanis Leatemia, 2013, Maluku in the Context of Development of Islands Province, Paper Presented at the National Seminar Day "Look Maluku 2013 : Maluku In the context of Indonesia Today and Tomorrow"; conducted by Center of Indonesian Journalists Association (PWI) cooperation with the Provincial Government of Maluku; Borobudur Hotel Jakarta, January 17, 2013.

${ }^{2}$ Franz Magnis Suseno, 2016, Political Ethics Basic Moral Principles of Modern Statehood, Gramedia Pustaka Utama, Jakarta, p. 444.
} 
rights are determined by law."

As a unitary state with the characteristics of the Indonesian archipelago, it adheres to the principle of decentralization. So that, the region is given the opportunity and power to regulate and manage its own household (regional autonomy) which is called an autonomous region. In this case, the Central Government has the authority to hand over part of its power to the regions based on the right to autonomy, but in the final stage the highest power remains in the hands of the central government. So the sovereignty, both internal sovereignty and external sovereignty, rests entirely with the central government. ${ }^{1}$ Article 18 paragraph (1) of the 1945 Constitution states further that "the Unitary State of the Republic of Indonesia is divided into provinces and the province is divided into districts and cities, each of which has a regional government, which is regulated by law."

The state science experts attempt to position the regional government philosophically, especially related to the purpose of state life, the position and role of the regional government in the state and constitutional constellation, as well as the principle values that need to be developed in the pattern of relations between the centre and the regions. ${ }^{2}$ The term divided as mentioned in article 18 of the 1945 Constitution is intended to emphasize that the relationship between the central and regional governments is hierarchical and vertical. ${ }^{3}$

The separation is done because the main characteristic of a unitary state (eenheidsstaat) is the authority owned by the central government which is then delegated to the regional government. Each unitary state can be organized according to principles and systems of centralization or decentralization. A centralized government can be fully run by and from the central government ( single centralized government ) or by the centre together with its organs scattered in the regions. Centralization which is accompanied by the dispersal of organs which carry out part of the authority of the central government in the region is known as de-concentration. Centralized government can also be carried out through decentralization where the authority to regulate and administer governance is not solely carried out by central government units, but by lower self-governing units that are independent (zelfstanding) and autonomous (territorial) or functional). ${ }^{4}$

There is also the relationship between the Central Government and the Regional Government which is further regulated in Article 18 A paragraph (1) of the 1945 Constitution as follows : "the relationship of authority between the central government and regional, provincial, district and city governments, or provincial and district and city governments, is regulated by law by taking into account regional specificities and diversity".

According to Article 18 A paragraph (1) of the 1945 Constitution, the relationship of authority between the central government and regional governments which is regulated legally, is carried out with due regard to the specificity and diversity of the region. It is intended that the implementation of this authority can optimize all the special potential and diversity of an area that is different from other regions in the archipelago.

As the largest archipelago in the world, geographical conditions are both opportunities and challenges for equitable distribution of national welfare. The regional government has a sea area larger than its land area, it certainly cannot be compared to other regions whose land area is wider than its sea area. The provinces of Maluku, North Maluku, Riau Islands, West Nusa Tenggara, East Nusa Tenggara, North Sulawesi, Bangka Belitung and Southeast Sulawesi are eight provinces whose seas are wider compared to other provinces in the country. This special geographical condition made the eight provinces demand that the central government give them special authority. ${ }^{5}$ The contents of the declaration are:

1. Affirming the principle of the struggle of the government and the people of the islands to uphold the Republic of Indonesia based on the Pancasila, the 1945 Constitution, and Unity in Diversity.

2. Agree to support the acceleration of the stipulation of the Draft Bill on the Islands Region into Law based on the national legislation program.

3. On the basis of legal certainty, before the stipulation of the Draft Bill on the Islands Region becomes a Law on the Islands Region, it urges the government to consistently and responsibly carry out the spirit of the provisions of Article 27, Article 28, Article 29 and Article 30 of RI Law No. 23 of 2014 concerning Regional Government, to accelerate the development of provinces characterized by islands.

Demands eight provinces with the archipelago's characteristic is recognition of Article 18 A paragraph (1) of the 1945 Constitution that each region in Indonesia has speciality and diversity. The regional speciality is specificity or privileges contained in each region, and the diversity of the region is that the regional disparities with other regions, each of which differ from each other. ${ }^{6}$ In this context, differences in the characteristics of

\footnotetext{
${ }^{1} \mathrm{Ni}$ ' Matul Huda, 2009, Local Government Law, Nusa Media, Bandung, p. 31.

${ }^{2}$ Dharma Setyawan Salam, 2004, Regional Autonomy in Perspective of Environment, Values and Natural Resources , Djambatan, Jakarta, p. 59.

${ }^{3}$ Jimly Asshiddiqie, 2002, Consolidation of the 1945 Constitution Manuscript After the Fourth Amendment , Center for Study of Constitutional Law, FH UI, Jakarta, p. 21

${ }^{4}$ Van der Pot, Handboek van Nederlandse Staatrecht, in Bagir Manan, 2004, Welcoming the 4th Dawn of Regional Autonomy, 2004, Centre for Law Studies at the Faculty of Law of UII, Yogyakarta, pp. 173 - 174.

The claim was stated in the Batam Declaration declared in Batam, Riau Islands Province on January 29, 2018. https://www.antaranews.com/berita/681378/d eight-provinsi-kep.islands-s agreements-deklarasi-batam

${ }^{6}$ Jimly Asshiddiqie, 2002 , Ibid. p. 23.
} 
terrestrial areas (continental) and aquatic terrestrial areas (land is greater than the sea), as well as the difference between them with terrestrial aquatic areas (islands or sea greater than land), should be a concern for obtaining arrangements in relation with the authority of the autonomous region in the sea. ${ }^{1}$

Maluku is one of archipelago's province. Its length of the coastline is the longest in Indonesia, namely $10,630 \mathrm{~km}^{2}$ or $11,17 \%$ of the total length of the Indonesian coastline, followed by the East Nusa Tenggara province 5.98\% and the North Maluku province 3.26\%. The terrestrial aquatic characteristics of the Maluku province are the total area of $712.480 \mathrm{Km}^{2}$, with $92.40 \%$ of the area being sea. The remaining area of $7.6 \%$ is land area. This means that the sea area of the Maluku province is 13 times greater than its land area. The vast area of the Maluku province which is dominated by the sea and islands, results in its area being geographically isolated; unequal distribution of population on 1,340 large and small islands and on the outer islands of the archipelago.

The God Almighty bestows the province of Maluku on a unique and different geographical condition from other regions in Indonesia. Having an economic value of natural resources, however, the province of Maluku is like a chicken that died in a rice barn. A province that is rich, but poor. A total of poor people in Maluku until July 2019, according to the Indonesia Central Bureau of Statistics still remain on the fourth rank populous province of the poorest most in Indonesia. ${ }^{2}$ It is the same as North Maluku province that experienced an increase in poverty during the period September 2018 - March 2019 which is 0.15 percentage points. ${ }^{3}$

The fulfillment of basic services (including education, health and social services) for the people of Maluku, which is a mandatory government regulation, has not been implemented properly. The indicators include: ${ }^{4}$

a) Minimum service standards for education have not been reached;

b) Limited quantity and poor quality of teachers;

c) Unequal distribution of teachers;

d) Limited education based on regional competence and local culture;

e) Islands-based health services are not yet optimal;

f) Limited inter and inter-island accessibility and connectivity;

g) The low quality of social services; and

h) The not yet optimal synergy in the implementation of protection and poverty reduction programs between the center and the regions.

Taking into account the geographical condition of the Maluku province, which has a wide sea area and there are many islands separated from one another, the concept of island cluster development is made. The concept of island cluster development is regulated in the Maluku Spatial Structure Plan of 1992, which states that what is meant by island cluster is the grouping of islands in space according to ecosystems, population, transportation, economy and agricultural potential..$^{5}$ In 1992, the territorial development in Maluku was grouped into 8 island group units. This grouping was based on geographical proximity, cultural similarity, natural unity, orientation tendencies, economic similarity and natural resource potential. Entering the reform era, with the Law No. 46 of 1999 concerning the Establishment of North Maluku Province, Buru Regency and West Southeast Maluku Regency, the division of Maluku province after the division was then divided into 8 island groups based on geographical proximity, cultural similarity of natural unity, orientation trends, economic similarity and natural resource potential .

The definition of the island cluster then underwent revision in the Regional Regulation of Maluku Province No. 2 of 2010 concerning the Maluku Regional Development Planning Conference. In the Regional Regulation of Maluku Province No. 2 of 2010 concerning the Maluku Regional Development Planning Deliberation referred to as the island cluster are:

"A collection of islands that are geographically close together, where there is a close relationship and have interdependence / interaction between ecosystems, economic, social and cultural conditions, both individually and in groups ".

The construction of island clusters in fact requires the support of the development of the island sea and plural gates. K rein sea islands by the Regional Regulation of Maluku Province No. 2 of 2010 concerning the Maluku Regional Development Planning Consultation are:

"The pattern of territorial sea area between regencies / cities in Maluku province as an economic unit and / or with other provinces bordering the Maluku province sea area, and is seen as part of the planning area, not as a barrier".

\footnotetext{
${ }^{1}$ Johanis Leatemia, supra note, p. 4.

${ }^{2}$ See https://www.bps.go.id/press-release/2019/07/15/239/berita-resmi-statistik.html ., Official News Statistics 15 July 2019 About Poverty Profile in Indonesia, accessed on July 16, 2019.

${ }^{4}$ See Regional Planning Agency of the Maluku Province.

${ }^{5}$ Seehttp://repository.ipb.ac.id/bitstream/handle/123456789/54873/BAB\%20VII\%20Model\%20Development\%20Gugus\%20Pulau.pdf?seque nce $=10$, accessed on August 2, 2017.
} 
The three marine areas included in the island's marine area are the Seram island marine area, the Banda island sea area, and the Arafura sea area. Each island cluster and island sea is expected to be the independent region, which is able to meet the needs of the region and develop their potential in a sustainable manner. At each island group the center of growth of the island cluster has been established, the development of which is expected to be able to push the surrounding area or the back region within the island group. Changes in the number of island clusters based on studies through the Spatial Planning of the Maluku Province in 2007-2027 are expected to guarantee accessibility, availability, acceptability, governance sustainability, and implementation of development and community service.

There is also a plurality set on an island cluster to help an island that does not have a dominant resource. Determination of plural doors in the area referred to as collector centers that can be used as exits and entrances in order to encourage the distribution of natural resources to the market and receive products that are needed by the community, but not produced in the island cluster. Determination of the plural doors in each island cluster is expected to develop into a center of industrial activity and services that must be complemented by supporting infrastructure development that is connected to the domestic, regional and international markets.

The ability of regional governments to exercise authority in international relations is a necessity in the era of globalization of the world which has penetrated all corners of the archipelago. The regional government as the executor of the government who is also a decision maker in strategic public policies such as investment and trade, will be very left behind if it does not blend into the association of the international community. As has been understood, the Law No. 23 of 2014 concerning Regional Government mandates the system of regional government with regional autonomy to run the wheels of government. Therefore, the region must comply with laws that apply to all regions of the Republic of Indonesia. However Indonesia with their laws specifically regional government should be able to explain and give a new regulation on maritime related to the specificity of the area. It is including how the provincial government which is characterized by the archipelago can utilize and develop its geographical peculiarities in establishing relations of foreign cooperation.

Foreign cooperation carried out by regional governments can be carried out after obtaining approval from the central government. Cooperation with foreign parties is not mandatory, as cooperation between regions is internal. Lex specialist for regional government guidelines in establishing foreign cooperation relations refers to the Minister of Foreign Affairs Regulation No. 09 / A / KP / XII / 2006/01 Concerning General Guidelines on Procedures for Foreign Relations and Cooperation by Regional Governments and Minister of Home Affairs Regulation No. 3 of 2008 concerning Guidelines for Implementing Regional Government Collaboration with Foreign Parties.

The expansion of the role of regional governments in the field of foreign cooperation requires the regional government to conduct diplomacy that can make a real contribution to the welfare of the region. SDGs contains 17 objectives and is divided into 169 targets were measured to make human life better. The 17 goals of the SDGs are as follows:

1. Without poverty;

2. Without starvation;

3. Healthy and prosperous life;

4. Quality education;

5. Gender equality;

6. Clean water and proper sanitation;

7. Clean and affordable energy;

8. Decent work and growth;

9. Industry, innovation and infrastructure;

10. Reduced gap;

11. Cities and communities are sustainable;

12. Responsible consumption and production;

13. Handling climate change;

14. Marine ecosystems;

15. Terrestrial ecosystems;

16. Peace, justice and strong institutional; and

17. Partnership to achieve goals.

The Maluku government is the founder of the island cluster, island sea, and plural gate development planning so that it has a great opportunity to participate in realizing global, national and local prosperity and prosperity through the para-diplomation of island clusters, island seas, and plural gates. However, this is difficult to do if the diplomacy carried out by the subnational entity itself in which it is not yet clear of its legal personality in international law. The Indonesian government is also very careful in giving freedom to regional governments to establish foreign cooperation, especially for regions that have a history of rebellion from the Republic of Indonesia such as Maluku. 
The arises problem then is that the Indonesian regional government in one hand has been given the authority to conduct foreign relations, but on the other hand, basically, the bureaucratic tradition of Indonesia is still inward looking, serving and dealing with citizens itself so that relatively no complex problems are encountered. In the era of globalization, the regional governments must be ready to change by outward looking or expanding the horizon of a more competitive bureaucratic vision by considering competition abroad, without leaving the main service mission to the public. The main keyword in this process is changing the mindset of the bureaucracy in the area from merely serving, to being brave to accept the challenges of progress. The SDGs agenda is a commitment of the international community that has been approved by countries in the world, including the Indonesian government. Therefore, the regional governments must support the central government in carrying out these commitments. The authority possessed by the central government in international law does not mean to impede the creativity and innovation of local governments to carry out activities that are international.

The Maluku regional government, through the concept of island group development, has a great opportunity to establish foreign cooperation. B erdasarkan Spatial Plan 2007-2027 year Moluccas province has set 12 island group as follows:

(1). The first island cluster includes Buru island;

(2). The island cluster II includes West Seram;

(3). The island cluster III includes North Seram;

(4). The island cluster IV includes East Seram;

(5). The island cluster V includes South Seram;

(6). The island cluster VI include Banda Island and Teon Nila Serua ;

(7). The island cluster VII includes Ambon Island and Lease Islands;

(8). The island cluster VIII includes the Kei Islands;

(9). The island cluster IX includes the Aru Islands;

(10). The island gr island cluster X includes the Tanimbar Islands;

(11). The island cluster XI includes the Babar Islands; and

(12). The island cluster XII includes the Islands of the South and Wetar Islands.

The Maluku government has identified the potential of natural resources in each group of islands, the utilization of which can be carried out through foreign cooperation. However, until now the foreign cooperation carried out by the Maluku government has not put forward the development of the island cluster itself which is the specialty of the Maluku province as a province with an archipelago.

\section{Conclusions}

The Maluku government which is characterized by archipelago can utilize its geographical peculiarities in establishing foreign cooperation relations. The Maluku government has carried out island cluster-based development, but the island cluster development has not been maximized by the regional government in establishing foreign cooperation relations. In fact, if this is done then the construction of this island group can support the implementation of SDGs, which is a commitment of the international community, especially in the Maluku region.

The region, as one of the most important elements of the country, is an opportunity for the region to be utilized for development and community welfare. Therefore, the Indonesian government needs to encourage the concept of island cluster development to become a characteristic of foreign cooperation from archipelagocharacterized regions so that with the opportunities it has, archipelagic regions can support the central government in implementing SDGs. This is absolutely done by the Indonesian government which is demanded by international law to participate in carrying out joint commitments to the nations of the world.

\section{References}

Books:

Dharma Setyawan Salam, 2004, Regional Autonomy in Perspective of Environment, Values and Natural Resources, Djambatan, Jakarta.

Franz Magnis Suseno, 2016, Political Ethics Basic Moral Principles of Modern Statehood, Gramedia Pustaka Utama, Jakarta.

Jimly Asshiddiqie, 2002, Consolidation of the 1945 Constitution Manuscript After the Fourth Amendment, Center for Study of Constitutional Law, FH UI, Jakarta.

Johanis Leatemia, 2013, Maluku in the Context of Development of Islands Province, Paper Presented at the National Seminar Day "Look Maluku 2013 : Maluku In the context of Indonesia Today and Tomorrow"; conducted by Center of Indonesian Journalists Association (PWI) cooperation with the Provincial Government of Maluku; Borobudur Hotel Jakarta, January 17, 2013.

Ni ' Matul Huda, 2009, Local Government Law, Nusa Media, Bandung. 
Van der Pot, Handboek van Nederlandse Staatrecht, in Bagir Manan, 2004, Welcoming the 4th Dawn of Regional Autonomy, 2004, Centre for Law Studies at the Faculty of Law of UII, Yogyakarta.

Websites:

https://sustainabledevelopment.un.org/futurewewant.html, accessed 5 June 2019.

http://www.un.org/ga/search/view_doc.asp?symbol=A/67/L.48/Rev.1\&Lang=E, accessed 5 June 2019.

https://sustainabledevelopment.un.org/content/documents/21252030\%20Agenda\%20for\%20Sustain able\%20Development\%20web.pdf, accessed 5 June 2019.

https://www.bps.go.id/press-release/2019/07/15/239/berita-resmi-statistik.html ., Official News Statistics 15 July 2019 About Poverty Profile in Indonesia, accessed on July 16, 2019.

http://repository.ipb.ac.id/bitstream/handle/123456789/54873/BAB\%20VII\%20Model\%20Development\%20Gu gus\%20Pulau.pdf? sequence=10, accessed on August 2, 2017. 